\title{
INTEGRATING TPCK PROCESS TO DEVELOP ENGLISH LEARNING ACHIEVEMENT OF UNDERGRADUATE STUDENTS
}

\author{
Sutthisin Suksabai ${ }^{1 *}$ and Potjanat Khoprasert ${ }^{1}$ \\ ${ }^{1}$ Suratthani Rajabhat University, Thailand
}

\begin{abstract}
The study aimed to compare students' English learning achievement between employing the Technological Pedagogical Content Knowledge Process (TPCK Process) and a conventional teaching method as well as to compare the English learning achievement of students before and after using the TPCK Process among 80 undergraduate students selected by the random sampling method. The students were divided into two groups; 40 students in the controlled group treated by a conventional teaching method and the other 40 students in the experimental group treated by the TPCK Process. The research instruments were twelve TPCK Process lesson plans, twelve conventional method lesson plans, and fifty items of English achievement test with difficulty index between 0.23-0.78, index of discrimination between $0.28-0.83$, and its internal reliability at 0.86 . Mean, percentage, standard deviation and t-test were used to analyze the collected data. The results revealed that the English learning achievement of students treated by TPCK Process was higher than those treated by the conventional teaching method at the significant level of $p<.05$, and students' English learning achievement was higher than after using TPCK process at the significant level of $p$ $<.05$.
\end{abstract}

Keywords: TPCK Process, conventional teaching method, English learning achievement

\section{Introduction}

Currently global trends play an important role in regulating strategic policies and development plans. Thailand cannot avoid facing various changes including adjustment to the surrounding changes such as the integration of economic groups as well as driving the country with information technology. Therefore, human resource development is a significant part of sustainable management for Thailand.

Thailand, as a member of the ASEAN community, has to operate in accordance with the framework and rules of the ASEAN Charter. According to the ASEAN Charter (Department of ASEAN Affairs, 2013), Article 34 states that "The working language of ASEAN shall be English." This has led Thailand to be account for accelerating the development of communication capacity in the English language among the citizens as English is a medium tool in communication in the ASEAN community and the second language of the ASEAN people, together with the first language of the natives (Onwimon, 2011).

However, the English language skills of Thai people have not been developed well. Based on the research of the Lifelong Learning Foundation (Sriprasit, 2009), which promotes the development of speaking, reading, listening and writing skills among Thai people, it is found that non-English speaking countries face the problems of reading and writing skills which have not yet met the criteria. This is because of the way of teaching English with emphasis on learning with memory that makes troubles reading new words such as illegible reading, unclear reading and guesswork is used to assist reading eventually. Additionally, Sriyoda (2012) found that most students had problems learning English because they are lack of knowledge of English, do not dare to speak or see the importance of learning English. 
Sangkapan, Boonprakarn, and Krairiksh (2015) studied the problems of learning English, such as problems with the teacher i.e. lack of skills in using modern technology like computers to help in teaching and learning. Teachers lack a variety of teaching techniques or they cannot create lessons to supplement their teaching. The problem with the learners is that most learners do not dare to speak or express themselves in learning activities. Some do not see the importance of English because they do not need it or think that English is a difficult subject. There is also a shortage of audio-visual equipment, graded reading books, or other resources as well as in-class teaching materials.

From the background and significance of the problems mentioned above, it is unavoidable to claim that one of the major problems comes from the teachers themselves. Teachers must have pedagogical content knowledge which comprises pedagogical knowledge and content knowledge to be able to design teaching plans. Knowledge is an important factor for a teacher since the teacher must always be aware that he is not only a knowledgeable person in the subject matter, but also a person who knows how to transfer the knowledge to the students well (Suksabai, 2016). However, for teaching in the $21^{\text {st }}$ century, the ability to use the technology in the instructional process in the classroom has been raised as a key issue in researches and development of learning processes in various courses (Sanrattana, 2013). As a result, teachers in the $21^{\text {st }}$ century need to have "Technological Pedagogical Content Knowledge" (TPCK) which consists of content knowledge (CK), pedagogical knowledge (PK), and technological knowledge (TK) (Harris, Mishra and Koehler, 2007). For this reason, the researchers are interested in using the TPCK teaching model by improving the teaching procedure and model from the pedagogical content knowledge (Suksabai, 2016) with the addition of technology media in order to assist in the promotion of English language teaching and learning. This concept is also the basis for the production and development of teachers to respond to the $21^{\text {st }}$ century world-class society, which focuses on incubation, creation and development of technology-based features. Strategic teaching in the scope of content is determined by the curriculum in its own field effectively and it is relevant to the characteristics. It is a learning management that can respond to the learning method of the learner and educational technology media can be beneficial to students, teachers, and educational management (Mediathailand, 2012). So, teachers in the $21^{\text {st }}$ century must be prepared to prepare students for the future.

All in all, teachers need to be alert and prepared to learn to prepare students for life in the $21^{\text {st }}$ century. The most important skills are learning skills of which focus is on knowledge, competency and skills as a result of the reform of teaching and learning as well as the preparation of various aspects contributing the learning to adjust to equality and change. Teachers must have knowledge in all dimensions; content knowledge, pedagogical knowledge, and technology knowledge. This is a framework and a way for researchers to adapt their teaching style in order to be consistent with the learning in this age. The TPCK instructional process is divided into four clear separated main steps between the activities of the teacher and the learner's activities. That is; step 1 provide knowledge and knowledge; step 2 organize learning activities through learning and teaching technology; step 3 organize activities to summarize or create knowledge and step 4 organize knowledge assessment activities and receive knowledge assessment.

\section{The Theory Framework of the Study}

Learning and Skills in the $21^{\text {st }}$ Century

The $21^{\text {st }}$ century learning and $21^{\text {st }}$ century learning concepts provide a strategic guideline for collaborative learning, creating models and practices for enhancing the effectiveness of $21^{\text {st }}$ century learning management. The new future skills concept is $21^{\text {st }}$-century learning that focuses on cognitive skills, expertise, and performance of students to live in a society of change. It refers to a model developed from the partnership for $21^{\text {st }}$ century skills, known as P21 (cited from http://www.p21.org). P21 has developed a conceptual framework for $21^{\text {st }}$ century learning by integrating specific knowledge and skills, expertise and knowledge of the various aspects together for the success of students in both work and life. The conceptual framework for $21^{\text {st }}$ century 
skills is recognized as the $21^{\text {st }}$ Century Outcomes and Support Systems. It is a conceptual framework that emphasizes student outcomes in core subjects and $21^{\text {st }}$ century skills to help students prepare in a variety of areas including learning support systems such as standards and assessments, curriculum and instructions, teacher development, and the right environment for learning in the $21^{\text {st }}$ century. The $21^{\text {st }}$ century learning must break through "subject" to "learning $21^{\text {st }}$ century skills", which students need to be self-taught while teachers will design the learning and practicing themselves to coaching and facilitating.

In order to see the $21^{\text {st }}$ century concept and approach to the development of the $21^{\text {st }}$ century curriculum, there are a number of organizations and academic institutions that provide a framework for $21^{\text {st }}$ century skills (Bellanca \& Brandt, 2010) as follows:

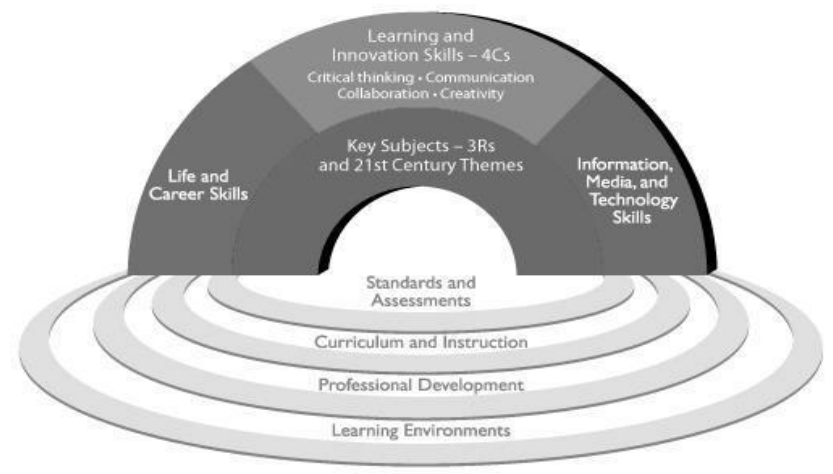

Figure 1: Conceptual Framework of Partnership for $21^{\text {st }}$ Century Skills

Source: Trilling, B. \& Fadel, C. (2009). 21 $^{\text {st }}$ Century Skills: Learning for Life in Our Times. San Francisco, John Wiley \& Sons.

1. Core Subjects - The No Child Left Behind Act of 2001 of the United States of America states core subjects as English, reading or language arts, mathematics, science, foreign languages, civics and government, economics, arts, history and geography.

2. $21^{\text {st }}$ Century Contents - This refers to important content in new fields to succeed in the workplace and community such as consciousness to the world, basic knowledge of finance, economics, business and entrepreneurship, citizenship, and awareness of health and welfare.

3. Learning Skills and Thinking Skills - In addition to learning academic content, learners need to know how to learn continuously throughout life. Learners must also learn to use what they learn effectively and creatively. Learning skills and thinking skills include critical thinking, problem solving, creativity and innovation, collaboration skills, contextual learning skills and basic information and media skills.

4. ICT Literacy - The basic knowledge in information and communication technology is the ability to use technology to develop knowledge and skills of the 21 st century in the context of learning core subjects. Learners must use technology to learn the content and skills and learn how to learn as well as critical thinking, troubleshooting, using information, communication, innovation production, and cooperation.

5. Life Skills - Good teachers know how to insert life skills into lessons. Life skills that should be promoted to the student include leadership, ethics, accountability, adaptability, knowing how to increase effectiveness, self-responsibility, skills to reach people, ability to self-direct and social responsibility. 
From the conceptual framework of $21^{\text {st }}$ century learning and skills, as a teacher, it can be concluded that the teacher must define the strategic approach to learning management. Forms and practices need to be developed to enhance the effectiveness of $21^{\text {st }}$ century learning management, expertise and competencies for students to live in today's changing society. From the conceptual framework of the Partnership for $21^{\text {st }}$ Century Skills, researchers are interested in using technology knowledge to develop the knowledge and skills of the $21^{\text {st }}$ century in the context of learning core subjects. Learners must be able to use technology to learn the content and skills and learn how to learn as well as critical thinking, troubleshooting, using information, communication, innovation production, and cooperation to gain fundamental knowledge of ICT literacy. In addition, the researchers see that current teachers must have more technology knowledge in addition to the content knowledge. This means the teachers must have technological pedagogical content knowledge or TPCK.

\section{Technological Pedagogical Content Knowledge: TPCK}

TPCK (Harris, Mishra and Koehler, 2007) is a knowledge that can be used as a concept of producing and developing a professional teacher to respond to the 21 st century world society. The TPCK concept is a contemporary concept developed from the pedagogical content knowledge by Shulman (1987). This innovative concept is used as a basis for developing professionalism for teachers in integrating technology as an important tool in classroom teaching by presenting a conceptual framework that is structured of basic knowledge and integrated knowledge which will lead to the development of quality needed for the knowledge that teachers should have in integrating the use of technology tools for teaching.

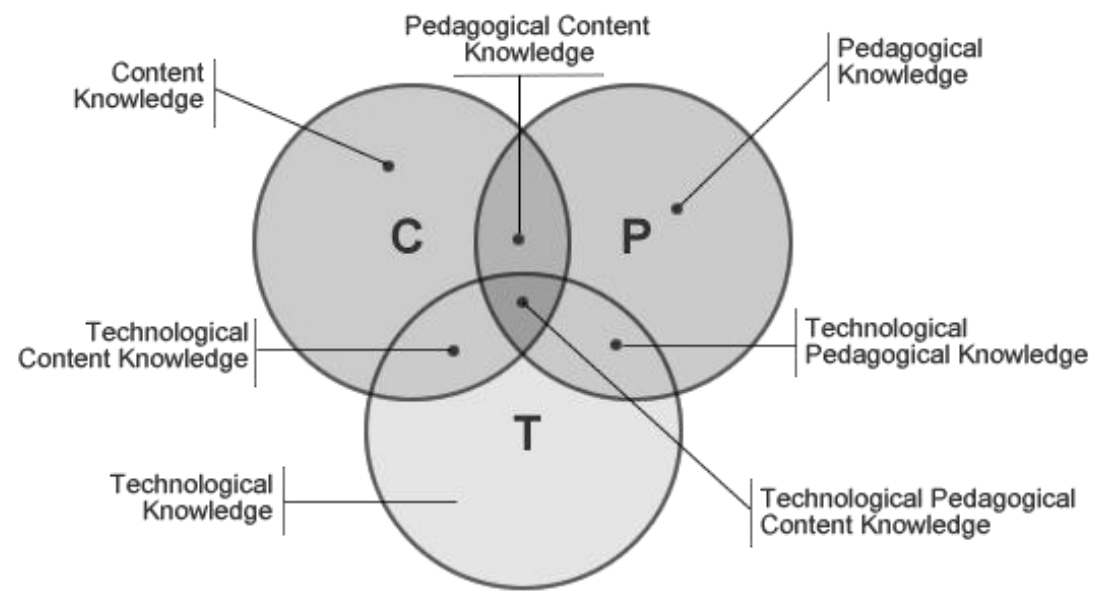

Figure 2: The Framework of Technological Pedagogical Content Knowledge

Source: Mishra, P. \& Koehler, M. J. (2006). Technology Pedagogical Content Knowledge: A Framework for Integrating Technology in Teacher Knowledge. Teacher College Record, 108(6), 1017-1054.

This technological pedagogical content is a knowledge characterized by a reciprocal link between knowledge in content, knowledge in teaching methods, and knowledge in technology. It involves the use of technology tools to create a representation of knowledge that facilitates teaching practices to promote access, to create a strategic technique for teaching, to simplify teaching tasks, and to develop instructional practices that are based on existing knowledge of the learner in a particular content. This creates an atmosphere and stimulates the interest of students to be more enthusiastic in learning.

From the framework of technological pedagogical content knowledge mentioned above, the researchers identified strategies for learning management by creating models and practices for enhancing the efficiency of learning management by modifying PCK process with the addition of technological knowledge in the step of 
organizing learning activities through learning and teaching technology in order to have the TPCK Process in English language teaching.

\section{Purposes of the Study}

This study aimed to compare students' English learning achievement between employing the technological pedagogical content knowledge process (TPCK Process) and a conventional teaching method, as well as to compare the English learning achievement of students before and after using the TPCK Process.

\section{Research Methodology}

The research framework of this study is an experimental design research on teaching (Campbell and Stanley, 1963). The population of this study was undergraduate students enrolling English Basics course (GED1003) in the second semester of the academic year 2017. The samples used in this research were 80 students by random sampling method. These students were divided into two groups; 40 students in the controlled group treated by the conventional teaching method and 40 students in the experimental group treated by TPCK Process. The research instruments were 1) twelve TPCK process lesson plans with the content validity derived from the index of item-objective congruence (IOC) between lesson plan elements and objectives at the level of 0.67-1.00, 2) twelve conventional lesson plans with the IOC level of 0.67-1.00, and 3 ) 50 items of English achievement test with the content validity derived from the IOC index of $0.67-1.00$, difficulty index of $0.23-0.78$, power index of $0.28-0.83$ and the reliability of 0.86 . The data were analyzed by mean, percentage, and standard deviation while the statistics used to test the hypothesis was the t-test.

\section{Research Results}

1. Comparison of English learning achievement between experimental group receiving TPCK teaching method and controlled group with conventional teaching method using t-test for independent samples to compare the critical values for significance as shown in Table 1.

Table 1 English Learning Achievement between Experimental Group $(n=40)$ and Controlled Group $(n=40)$

\begin{tabular}{llllll}
\hline Group & $\overline{\mathrm{X}}$ & Percentage & S.D. & $\mathrm{t}$ & Sig. \\
\hline Experimental Group & 28.90 & 57.80 & 2.88 & $8.552 *$ & .000 \\
Controlled Group & 23.45 & 46.90 & 2.82 & & \\
\hline $\mathrm{P}<.05$ & & & & &
\end{tabular}

The findings from Table 1 indicate that the percentage of the English learning achievement between the experimental and controlled group is $57.80(\overline{\mathrm{x}}=28.90$, S.D. $=2.88)$ and $46.90(\overline{\mathrm{x}}=23.45$, S.D. $=2.82)$ respectively. The result of paired sample t-test shows that the English learning achievement of the experimental group is significantly higher than the controlled group at the level of .05.

2. Comparison of pretest and posttest learning achievement of learners taught by TPCK using t-test for dependent samples to compare the critical values for significance as shown in Table 2.

Table 2 Pretest and Posttest Learning Achievement of Learners Taught by TPCK Process ( $n=40)$

\begin{tabular}{llllll}
\hline Group & $\overline{\mathrm{X}}$ & Percentage & S.D. & $\mathrm{t}$ & Sig. \\
\hline Pretest & 21.55 & 43.10 & 3.59 & $18.468^{*}$ & .000 \\
Posttest & 28.90 & 57.80 & 2.88 & & \\
$* \mathrm{P}<.05$ & & & & &
\end{tabular}


The table 2 displays the pretest and posttest English learning achievement at the percentage of $43.10(\overline{\mathrm{x}}=21.55$, S.D. $=3.59)$ and $57.80(\overline{\mathrm{x}}=28.90$, S.D. $=2.88)$ respectively. There is also a statistically significant difference at the .05 level, indicating that after learning, the experimental group taught by TPCK Process has a higher English achievement score in the posttest than the pretest.

\section{Research Discussions}

According to the research results, it can be discussed as follows:

1. Based on the data analysis, it was found that the mean of posttest scores of the experimental group taught by the TPCK was 28.90 which was higher than the mean of posttest scores of the controlled group taught by the conventional method equal to 23.45 . When tested for the hypothesis, the t-test for independent samples was used to compare the critical values for significance (Srisa-ard, 2011). From this, the mean scores of the posttest scores on English language learning achievement in the experimental and controlled groups were statistically significant at the .05 level. This means that teaching by using the TPCK process resulted in a higher level of English learning achievement than the conventional teaching method, which conformed to the set assumption. This may be due to the fact that the TPCK process is the integration of knowledge between the content, pedagogy, and technology for teaching and learning, so it will lead to an understanding of how to teach or teach topics so that learners with different abilities became more interested and understood (Shulman 1987; Harris et al. 2007). The teacher can integrate other knowledge outside the classroom or plan for the supplement which attracts TPCK learners. The finding also complies with Khammani (2009) who emphasized on teaching with integration. TPCK teaching is a popular integrated teaching approach because of the combination of a content, a pedagogy, and technology. This is also consistent with educational theories that focus on holistic development. Therefore, in implementing the TPCK process in teaching English, teachers need to have the knowledge of teaching content by using technology to teach English and students so that the learning achievement can be higher than the normal teaching.

2. From the data analysis, it was found that the mean of posttest scores of the TPCK learning group was 28.90 which was higher than the average of the pretest means of 21.55 . When tested for the hypothesis, the t-test for dependent samples was used to compare the critical values for significance (Srisa-ard, 2011). From the test, it was found that the mean score of the posttest and pretest of the experimental group taught by the TPCK process was significantly different at the .05 level. The teaching of the TPCK process has eventually resulted in higher learning achievement in English than before as assumed. This may be due to a clear sequence of steps between the teacher and the learner, based on the knowledge of teaching the content by technology (Harris et al. 2007). In teaching management, teachers must have knowledge concerning the use of technology tools to create a knowledge representative that is conducive to teaching to promote the understanding of English. In addition, the use of technology tools to create strategic techniques of English teaching, to help reduce the difficulty of teaching English, to improve the learning process of English learners, and to create a teaching guideline that is based on the existing knowledge of the learner and consistent with the theory of knowledge contributes the atmosphere to the motivation learners to become more enthusiastic in learning English.

Throughout the research, it indicates that teaching English through the TPCK process is an instructional model that emphasizes integration and is a model that develops learners' learning at the same time by integrating the content, methodology, beliefs, and knowledge of teachers into the English content, which is topic-specific because teaching through the TPCK process can be effective when depending on the subject level that teachers have specialized. That is, teachers ought to have the technological pedagogical content knowledge comprising content knowledge, pedagogical knowledge, and technological knowledge to construct teaching plans. At present, this knowledge is an important factor for teachers directly because they must always consider that they are not only knowledgeable about subjects, but they must be a knowledge transfer to students as well through 
modern technology in the framework of $21^{\text {st }}$ century learning (Trilling and Fadel, 2009). For this reason, learners who have been taught by the TPCK process could gain achieve English learning than before.

\section{Recommendations}

Recommendations for Applications:

1. To organize learning activities using the TPCK process, teachers must be well-prepared with the technological knowledge, pedagogical knowledge, and content knowledge from the prepared teaching plans. Media and venues for teaching and learning activities must be readily available and advantageous to the learning activities.

2. To make groups of students, it should include students with different abilities so that they can help each other within their groups.

3. Teachers should allow students to complete the activity and evaluate them within class time.

Recommendations for Further Studies:

To enable the TPCK process to become more widely known, it should be considered on the following issues:

1. There should be a research conducted to study the effects of using the TPCK process to develop English skills individually.

2. There should be a research on using the TPCK process in other learning areas apart from English.

3. It should be studied the effects of using TPCK process at other grade levels. Particularly, higher level students are required because the subject matter is more specific.

4. The comparison or integration the TPCK process with other teaching methods should be researched to find out the effectiveness of the pedagogy.

\section{Acknowledgements}

We would like to express our deep and sincere gratitude to all those who gave us the possibility to complete this study. It is great pleasure to thank our staff at English Program, Faculty of Education, Suratthani Rajabhat University, for giving many suggestions and additional ideas until this study has been completed. In addition, we are indebted to our students for providing us an opportunity to do this research. They were well-cooperated and made a stimulating atmosphere in their class. Without them, this research could not have been accomplished.

\section{References}

Bellanca, J. \& Brandt, R., 2010, $21^{\text {st }}$ Century Skill: Rethinking How Students Learn (Bloomington, US: Solution Tree Press).

Benefits of Technology, Date of access: 18/02/2018. http://mediathailand-ictedu.blogspot.com/2012/05/35.html. Campbell, D. T., \& Stanley, J. C., 1963, Handbook of Research on Teaching (Chicago, US: Rand Mcnally).

Department of ASEAN Affairs., 2013, 58 Answers towards ASEAN Community 2015 (Bangkok, Thailand: Department of ASEAN Affairs, Ministry of Foreign Affairs).

Framework for $21^{\text {st }}$ Century Learning, Date of access: 09/01/2018. http://www.p21.org/about-us/p21framework. 
Harris, J., Mishra, P., \& Koehler, M. J., 2007, Teachers' Technological Pedagogical Content Knowledge: Curriculum-based Technology Integration Reframed, Paper Presented at the Annual Meeting of the American Education Research Association, Chicago, US.

Khammani, T., 2009, Teaching Knowledge to Effective Learning Management (Bangkok, Thailand: Chulalongkorn University).

Mishra, P. \& Koehler, M. J., 2006, Technology Pedagogical Content Knowledge: A Framework for Integrating Technology in Teacher Knowledge, Teacher College Record, 108(6), 1017-1054.

Onwimon, S., The use of English and other languages in the region and the future of Thailand in ASEAN, Date of access: 25/11/2017. http://varieties-thailand.blogspot.com/2011/07/1-2_20.html.

Sangkapan, J., Boonprakarn, K., \& Krairiksh, W., 2013, Situations and Problems in Learning English at Secondary Schools Affiliated with Municipalities in the Three Southern Border Provinces, Proceedings of the $6^{\text {th }}$ Hatyai National Conference, Hat Yai, Thailand.

Sanrattana, W., 2013, New Educational Paradigm: A Cast Study of the $21^{\text {st }}$ Century Education (Bangkok, Thailand: Thipayawisut).

Shulman, L. S., 1987, Knowledge and Teaching: Foundations of the New Reform. Harvard Educational Review, 57(1): 1-22.

Sriprasit, I., 7 Steps to Make Thai People Good at English Permanently, Date of access: 25/11/2017. http://oknation.nationtv.tv/blog/englishclinic/2009/06/24/entry-3.

Srisa-ard, B., 2011, Fundamentals of Research, $9^{\text {th }}$ edition (Bangkok, Thailand: Suweeriyasan).

Sriyoda, S., 2012, Problems of Learning English at Matthayomsuksa 3 in Opportunity Expansion Schools under the Office of Phatthalung Primary Education Area Region 1, (Unpublished Master's Thesis), Prince of Songkla University, Hat Yai, Thailand.

Suksabai, S., 2016, Using Pedagogical Content Knowledge Process to Develop English News Reading Skills of Mathayom Suksa V Students, Proceedings of the $6^{\text {th }}$ STOU National Research Conference, Nonthaburi, Thailand.

Trilling, B. \& Fadel, C., 2009, $21^{\text {st }}$ Century Skills: Learning for Life in Our Times (San Francisco, US: John Wiley \& Sons). 